\title{
The Mir Crew Safety Record: Implications for Space Colonization
}

\author{
Marilyn Dudley-Rowley* \\ OPS-Alaska, 2262 Magnolia Avenue, Petaluma, California USA 94952
}

\begin{abstract}
[Abstract] In 1985, Rockwell International (now Boeing-North American) completed the Space Station Crew Safety Alternatives Study for NASA. This five-volume study identified a wide range of potential safety threats and hazards that the crew might encounter on the future International Space Station. These threats included fire, explosion, collision, decompression, contamination, and radiation, among many others. One volume focused on the human factors aspects of safety, featuring the Crew Safety-Human Factors Interaction Model. In this model, a stressor (such as one of the threats) can lead to degraded performance, which can contribute to human error, unless appropriate and effective countermeasures are available to the crew. In 1986, the Soviet Union launched the Mir Space Station, the "second generation" that followed the Salyut series of space stations. The Mir was designed for a five-year life on orbit. It remained in use for fourteen years. During the first ten years, it performed well, with few safety issues. However, during the last four years, the aging station -- operating at more than two times beyond its design lifetime -encountered a variety of safety hazards and human factors issues. Despite these often serious problems, the Mir crews always found a way to save the station, and no crew member was seriously injured or killed. This paper evaluates the safety record on Mir, and compares it to the NASA-Rockwell study, that was contemporaneous with the construction and launch of Mir. This comparison and analysis can provide a foundation for future space crew safety, related human factors support, and ultimately the human colonization of space.
\end{abstract}

\section{Keywords}

Space station crew safety, Cohen and Junge Model, countermeasures against stress, countermeasures against errors, safety hazards

\section{Introduction}

$\mathrm{I}^{\mathrm{N}}$ 1985, Rockwell International (now Boeing-North American) completed the Space Station Crew Safety Alternatives Study for NASA. This five-volume study identified a wide range of potential safety threats and hazards that the crew might encounter on the future International Space Station. These threats included fire, explosion, collision, decompression, contamination, and radiation, among many others. One volume focused on the human factors aspects of safety, featuring the Crew Safety-Human Factors Interaction Model (Figures A,1-5). In this model, a stressor (such as one of the threats) can lead to degraded performance, which can contribute to human error, unless appropriate and effective countermeasures are available to the crew.

In 1986, the Soviet Union launched the Mir Space Station, the "second generation" that followed the Salyut series of space stations. The Mir was designed for a five-year life on orbit. It remained in use for fourteen years. During the first ten years, it performed well, with few safety issues. However, during the last four years, the aging station -- operating at more than two times beyond its design lifetime -- encountered a variety of safety hazards and human factors issues. Despite these often serious problems, the Mir crews always found a way to save the station, and no crew member was seriously injured or killed.

Different people have looked at Mir and have seen different things: a national symbol, a way to generate funds for the space enterprise, a place for space flyers to test their mettle, or an opportunity to score points on the international stage for politicians from different nations. In the long run, all these ways to view the Mir space station will take a backseat behind the picture that it gave us of things to come. To those of us who seriously study the long-

${ }^{*}$ CEO and Founding Researcher, OPS-Alaska, AIAA Member. 
duration space mission and issues of safety in space, when the fog of politics clear, when the minutiae of everyday life in our interdependent world are put into perspective, we will see that Mir was a critical testbed and a major beachhead for the longer journey that awaits humanity. The length of operation of Mir beyond its projected use-life and the events that occurred during the long-duration missions of its cosmonauts and astronauts are a testament of what can be expected and what is needed to operate a technologically complex system on extended missions in the extreme environment of space and to work and live aboard it.

This report examines safety issues concerning long-duration spaceflight as exemplified by the Mir experience, especially in the details from the Mir-NASA mission record. The authors compare that record to the NASARockwell study, that was contemporaneous with the construction and launch of Mir. This effort, a pilot study, far from complete, is significant for two reasons. Firstly, for history, it will bear witness to the tremendous role Mir played in the expansion of the human ecology. Secondly, this comparison and analysis - which the author hopes to expand -- can provide a foundation for future space crew safety and related human factors support.

In the long run, the investigator seeks to know how predictive the Rockwell study was, and to know if it is a good instrument for use. This pilot study focused on a portion of the study interested in the safety impact of human factors, in particular, a model called the Space Station Crew Safety Human Factors Interaction Model. The investigator also calls this model the Cohen and Junge Model.

\section{History of Ideas}

The history of ideas of extended duration spaceflight prior to 1985 was informed directly by two American efforts that did not reach full fruition and two generations of Russian space stations, embraced by Salyuts 1-7, not all of which were crewed. Now, to be remembered, there were actually two separate programs under the Salyut name, two entirely different configurations of space station for two entirely different purposes. Salyuts 1, 4, 6, and 7 were the scientific configuration. Salyuts 2, 3 and 5 were basically for the purpose of military reconnaissance (Almaz configuration). Salyut 2 failed, breaking up in orbit. The Almaz design was a similar configuration as the U.S. Air Force's Manned Orbiting Laboratory (MOL). The MOL was based on Gemini technology, which made it to preliminary hardware stage, but was never flown. About a month after Salyut 2's demise, the United States launched Skylab. After a misadventure upon launch, Skylab attained orbit, but was uninhabitable until repairs could be effected by the first crew. That first crew saved the Skylab program, commanded by Charles "Pete" Conrad. Over the entire Salyut and Almaz programs, there were a number of failures that did not merit the Salyut designation. And, then, a design feature was deployed that put the Salyut scientific configuration into the next generation. Salyut 6 and 7 had docking ports fore and aft, which meant that they were resuppliable while a crew was aboard. This could enable long-duration missions, and could rightly be called another generation of space station within the Salyut series. Ironically, Skylab had the same feature. However, this surviving remnant of the broader vision of the Apollo applications program, which would have included a much more ambitious space station agenda, was truncated to a three-crew program owing to new constraints on the NASA budget.

So, the American history of ideas informing space station crew safety was still largely a chronicle yet to be written at the time of the Space Station Crew Safety Alternatives Study. By 1985, those who participated in that study for NASA knew that the United States was over-invested in the human-technology human factors interface. In other words, the American space program was primarily concerned with the engineering technology required to put a man on the Moon. Medical requirements for survival was a related part, but basic biological research trailed behind and the psychosocial human factors were not an object of study for the most part.

The Crew Safety Alternatives study team knew that psychosocial phenomena would assume a salient role in long-duration space missions. Its final report warned that American astronauts were traditionally trained to complete heavy on-orbit workloads with clearly defined tasks and goals. Being typically test pilots, these astronauts were accustomed to a great deal of stress and danger (Rockoff, Raasch, and Peercy, p. 1). ${ }^{1-5}$ Implied, as well as expressly stated, were the cautionary notes that space station crews would be comprised largely of persons without test pilot training and that tasks and goals aboard station might not be so clearly defined minute-by-minute. Crew mixtures would change, durations of missions would extend, and it could be expected that stress would increasingly impact safety.

Approaching the problem of human factors and safety interaction, a number of avenues were followed. The Crew Safety Alternatives study team identified discrete sub-elements that related to safety and placed those elements in a personal/habitability matrix. Independently, it so happened, NASA's Marc Cohen and Maria K. Junge approached the identification of these sub-elements through the stressor route.

The Crew Safety Alternatives study team identified several diagnostic stressors by examining life at Antarctic research stations, aboard submarines, and on board the Skylab 4 mission, the third manned mission of the Skylab 
program. These stressors were discussed in some detail in Volume III of the Final Report. By comparison, the Cohen and Junge model lent another level of sophistication to the effort in that it bridged space stressors to discrete human factors issues. This model (Figures A, 1-5) attempted to show some degree of cause and effect between environmental and operations conditions and the creation of potential safety hazards. Cohen and Junge wrote (p. 11):

The intermediary steps between these two extremes of causality were the effects of human performance and the results of degraded performance. The model contains three milestones: stressor, human performance (degraded) and safety hazard threshold. Between these milestones are two countermeasure intervention points. The first opportunity for intervention is the countermeasure against stress. If this countermeasure fails, performance degrades. The second opportunity for intervention is the countermeasure against error. If this second countermeasure fails, the threshold of a potential safety hazard may be crossed.

\begin{tabular}{|c|c|c|c|c|}
\hline \multicolumn{5}{|c|}{ Figure A } \\
\hline STRESSORS & $\longrightarrow$ & $\begin{array}{c}\text { DEGRADED } \\
\text { PERFORMANCE }\end{array}$ & 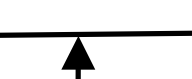 & $\begin{array}{l}\text { SAFETY } \\
\text { HAZARD }\end{array}$ \\
\hline & $\begin{array}{c}\text { COUNTER- } \\
\text { MEASURES } \\
\text { AGAINST STRESS }\end{array}$ & & $\begin{array}{c}\text { COUNTER- } \\
\text { MEASURES } \\
\text { AGAINST } \\
\text { ERRORS }\end{array}$ & \\
\hline
\end{tabular}

The Cohen and Junge model -- in other words, the Space Station Crew Safety Human Factors Interaction Model -- would come to be included in the findings of the Crew Safety Alternatives study team as a matter of conjoined history. At the beginning of the Space Station Advanced Development Program in 1984, the Office of the Chief Engineer at NASA Headquarters commissioned the Space Station Crew Safety Alternatives Study from Rockwell International. The group at Rockwell was the Space Shuttle Safety team, many of who had also worked on the Apollo lunar, Apollo-Skylab, and Apollo Soyuz programs. The study was to be published in five volumes, including a volume dedicated to the human factors aspects of safety. Then, Dr. Milton Silveira, the NASA Chief Engineer asked the AeroSpace Human Factors Division at NASA-Ames Research Center to manage that volume of the study. Marc M. Cohen was selected to serve as the "contract monitor's technical representative" (COTR) for Volume III concerning human factors aspects of safety. Mr. Cohen, an architect with the title AST-Manned Systems was in the Space Human Factors Office. The Office Chief was Dr. Trieve Tanner, a licensed clinical psychologist, who made many valuable suggestions throughout the entire project, including a detailed review upon completion.

However, before it would be possible to give direction to the Rockwell team, it was necessary for the NASAAmes researchers to plan their approach, which they believed required both a theoretical framework and a practical construct. The combined theoretical and practical approach became the Space Station Crew Safety Human Factors Interaction Model. Ms. Maria Junge, an industrial engineer and mathematician in the Space Human Factors Office, helped Mr. Cohen substantially in preparing and documenting the model. When the model was completed and represented graphically in its final form, Dr. Tanner presided over a review of the model by scientists in the Aerospace Human Factors Division. Once it passed review, Cohen and Junge presented it to the Rockwell Crew Safety team as the basis for the Human Factors volume of their study. Mr. Cohen oversaw the development of the study through the next year. The Rockwell team presented their final report to the NASA Chief Engineer, Dr. Silveira, in Washington, and then at all the NASA Centers involved in the Space Station program

Cohen and Junge, thus, devised a model that focused on habitation and work life aboard a space habitat (Figures 1-5). The stressor sub-elements of the Crew Safety Alternatives study team and the stressor sub-elements identified by the NASA team of Cohen and Junge were compared for correlation. The correlation factor was high (Rockoff, Raasch, and Peercy, p. 1).

\section{Methodology}

Thinking about natural phenomena in a systematic way is a hallmark of the scientific method. This study is consistent with methodological themes advocated by the author elsewhere that 1) social and behavioral phenomena are natural phenomena and 2) all human factors interfaces of long-duration spaceflight need to be addressed in systematic ways (Dudley-Rowley 1999, Dudley-Rowley, Bishop, Farry, and Gangale 2000, Dudley-Rowley, Whitney, Bishop, Caldwell, and Nolan 2001, Dudley-Rowley and Bishop 2002, Dudley-Rowley, Okushi, Gangale, Flores, and Diaz 2003). ${ }^{6-9}$

Would the systematic construction of Cohen's and Junge's Human Factors Interaction Model relate to actual events aboard the Mir? And, how robustly predictive would it be? The authors compared the model with the record of several Mir missions to find out. Information about the seven Mir-NASA missions has been knit together from 
several accounts written by astronauts and others who have examined mission transcripts. To round out the picture, personal communications have contributed in some cases, as have reports written about astronaut and cosmonaut health.

The different segments of the model are shown in Figures 1-5, representing the original enumeration of the different segments in the Space Station Crew Safety Alternatives Study. In most cases, examples of each stressor named in the Cohen and Junge Model could be found present in the missions. The author was also able to examine the chain of events following the stressors to see how countermeasures or failure to employ them played out. In this way, the investigator found evidence for countermeasures that had not been predicted and obtained a better view of a wider array of safety hazards that confront astronauts and cosmonauts on space stations.

\section{Results}

\section{Figure 1. Protocols}

(Stressors exacerbated by varying degrees of autonomy from ground)

\begin{tabular}{|c|c|c|c|c|}
\hline STRESSORS & $\begin{array}{c} \\
\text { COUNTER- } \\
\text { MEASURES } \\
\text { AGAINST } \\
\text { STRESS }\end{array}$ & $\begin{array}{c}\text { DEGRADED } \\
\text { PERFORMANCE }\end{array}$ & $\begin{array}{c}\prod_{\text {COUNTER- }} \\
M E A S U R E S \\
\text { AGAINST } \\
\text { ERRORS }\end{array}$ & $\begin{array}{l}\text { SAFETY } \\
\text { HAZARD }\end{array}$ \\
\hline $\begin{array}{l}\text { Scheduling } \\
\text { Overload }\end{array}$ & $\begin{array}{c}\text { Scheduling } \\
\text { Changes; Crew } \\
\text { Rotation }\end{array}$ & Scheduling Conflict & $\begin{array}{l}\text { Daily Scheduling; } \\
\text { Staff Meetings }\end{array}$ & $\begin{array}{c}\text { Lack of } \\
\text { Coordination; } \\
\text { Misunderstanding }\end{array}$ \\
\hline Family Problems & $\begin{array}{c}\text { Family } \\
\text { Interaction; } \\
\text { Secure } \\
\text { Communication } \\
\text { s }\end{array}$ & $\begin{array}{c}\text { Abnormal Behavior; } \\
\text { Depression }\end{array}$ & $\begin{array}{l}\text { Discipline; } \\
\text { Counseling }\end{array}$ & $\begin{array}{c}\text { Deliberate } \\
\text { Conflict; Inability } \\
\text { to Work }\end{array}$ \\
\hline $\begin{array}{c}\text { Disagreements } \\
\text { with Ground } \\
\text { Control }\end{array}$ & $\begin{array}{l}\text { Autonomy from } \\
\text { Ground }\end{array}$ & $\begin{array}{l}\text { Conflicting } \\
\text { Objectives }\end{array}$ & $\begin{array}{l}\text { Changes in } \\
\text { Mission } \\
\text { Objectives }\end{array}$ & $\begin{array}{c}\text { Violation of Safety } \\
\text { Criterion }\end{array}$ \\
\hline Territoriality & $\begin{array}{l}\text { Access/Non- } \\
\text { access }\end{array}$ & Turf Conflicts & Negotiations & $\begin{array}{l}\text { Improper Entry or } \\
\text { Inadequate Access }\end{array}$ \\
\hline Incompatibilities & $\begin{array}{l}\text { Crew Selection; } \\
\text { Crew Training }\end{array}$ & Incompatibilities & $\begin{array}{l}\text { Training; Group } \\
\text { Process }\end{array}$ & $\begin{array}{c}\text { Lack of } \\
\text { Cooperation }\end{array}$ \\
\hline
\end{tabular}

\section{A. Scheduling Overload}

The issue of scheduling overload occurred during the flight of the third crew aboard the American space station, Skylab. The crew switched off communications with the ground for a whole day and spent that period recuperating by free-lancing their own time - largely looking out the window. Ground controllers could not understand why the third crew were not as "workaholic" as the second crew. From an examination of the records available, they seemed to view the incident as an anomaly, perhaps a display of elite astronaut prerogative. Had Skylab remained on orbit, NASA would have learned what it had to learn much later aboard Mir. In terms of workload, a tour-of-duty aboard a space station cannot be played out like a never-ending shuttle mission. As Mir astronaut John Blaha complained, his youthful NASA ground team thought they were working a shuttle mission, and was supremely flustered that they would not take his recommendations, someone who had been on four shuttle missions before his Mir tour-of-duty (Burrough, p. 108). ${ }^{10}$

Shortly into Blaha's tour-of-duty, his cosmonaut fellows tried to intervene and to convince him that he had to rest, to conserve his psychological energy, and to not work constantly. This is a clear example of attempting a countermeasure against stress. However, American astronauts are driven by similar motivations that drive Russian cosmonauts. They want to do a good job and to fly again. For the astronaut, what would win him or her kudos was completing his work that had been assigned to him by NASA while he or she was on orbit. Most often that work was conveyed to NASA by American universities and corporations that had spent millions of dollars to have in-flight experimental programs. If the astronaut did not perform up to expected standards (standards that have been based on short shuttle flights), then he or she might not fly again. Mir commander Valery Korzun told Blaha that he had to get 
his ground people to understand the realistic time that was needed to do his on-orbit work. When it looked like Astronaut Blaha was continuing to be overloaded and his performance had degraded, Commander Korzun "pulled rank" as the Mir's master during a communication period with the ground, addressing the ground in such a way that the Americans in Russian Mission Control (the TsUP) understood that he did not want his astronaut crewman abused any longer. Commander Korzun's countermeasure against error worked. John Blaha's load was reduced.

Upon hindsight, several reasons become clear why it was that the NASA ground team did not recognize the features of scheduling overload. Among them were: 1) NASA's lack of experience in features of long-duration flight, 2) the relative inexperience of the youthful NASA ground team present at the TsUP, 3) the first Mir astronaut Norm Thagard had not been overloaded owing to a snafu with his experiments and so did not experience the condition of overload, and 4) the previous Mir astronaut, Shannon Lucid, simply did not complain much about her overloaded schedule, which should have been expected from a female space flyer. ${ }^{\dagger}$

During later Mir missions, the crews were subjected to a series of problems (i.e., a fire, decompression) that compromised the structural integrity of the station. Add to that leaking antifreeze and various episodes of rising $\mathrm{CO}_{2}$ levels and health and lives were at stake. At this point in the life of Mir, space flyers were, as a matter of course, overloaded. The only countermeasures at this point were countermeasures against error and they took them. However, owing to the scope of these problems, "daily scheduling and staff meetings" were more on the order of "round-the-clock work till they dropped and conferring with the Ground at every opportunity." These countermeasures came in the form of continual discussions among the crew and between the crew and ground "working the problems" and on-orbit, hands-on attempts to ameliorate the problems.

\section{B. Family Problems}

This is a prickly issue and therefore an area where few real data exist. Space flyers do not like to disclose anything that smacks of "family problems" on or off orbit. Messy divorces, for example, are bad publicity for space agencies, and some astronauts have suspected that such problems have caused them to be passed over for flights. Even the August 2003 wedding via radio of Cosmonaut Malachenko and his betrothed on the ground raised eyebrows among space officials - though the story made for good publicity following the grief of the Columbia disaster. Perhaps there would not have even been a wedding had the bride's family not hired a capable Houston publicist to martial the event. Alas, the issue of family problems is as big a bugaboo as the topic of "sex in space." Unfortunately, family problems are very real and more likely to occur than a couple of amorous space flyers finding an intimate moment on orbit. The odds are that astronauts and cosmonauts simply carry the knowledge of any ongoing family problems into space with them and keep quiet about them - because they want to fly. There are pressures on the Ground side not to bring up any family problems that emerge while space flyers are on orbit. Why shouldn't supervisors attach a priority to not revealing family issues to people trying to do a job in space, a job that has so many costs and agendas attached to it? While this game of silence might be effective over the short-duration, over the long-duration, pretending that there are no problems when there are or trying to minimize them are not effective responses on the parts of either the Ground team or the on-orbit team. When the day comes that more crews are increasingly on orbit for increasingly longer period of time, when space work is more like a military tourof-duty or like a stint on a semi-submersible oil rig at sea, the issue of family problems will increase in importance.

So far, communications with family members have been an adequate countermeasure against stress when space flyers have worried about their loved ones. But, the question arises, what happens when a spouse blurts out in a communication that he or she wants a divorce when a space flyer is on orbit? Much better than Ground ordering the space flyer to "forget about it" or simply "stay tough" would be to offer counseling as a countermeasure against stress, a first line of defense, than to wait and bring it in as a countermeasure against error. Other sorts of family problems might be lessened by the space agencies providing some sort of organized family assistance that either formally or informally has been in place all along.

\section{Disagreement With Ground Control}

By now, it is known that the impasse between Skylab's third crew and Mission Control was no anomaly. Also, cosmonauts Lebedev and Berezevoy aboard Salyut 7 periodically disagreed with the ground. The most extended example of this was the disagreements between the TsUP and Tsibliev and Lazutkin aboard Mir. If Mir in time will

\footnotetext{
${ }^{\dagger}$ There is much revealed in the often-heard comment about women in traditionally men's professions - that they have to be "more manly" than the men in order to simply maintain their standing in the field. Because any complaints would have been interpreted as an expected "weak sister" property or trait, and could be used as an argument advocating against women in space, female astronauts and cosmonauts, like any female extreme environmental worker, do not normally complain.
} 
be appreciated as the beachhead for humankind entering the Cosmos on a permanent basis, Tsibliev and Lazutkin will go down in history as major figures in gaining that beachhead. There was much more for them to respond to along the entire array of human factors interfaces because so much happened on their watch. Few crews have faced what those two cosmonauts and their fellows faced before, the Apollo $13 \mathrm{crew}$ certainly to be remembered among those very few.

There is much to discover by studying their time on orbit, and much to be lost by simply characterizing them as an unruly team that argued a lot with the Ground. Certainly, much of their conflictual communication between these space flyers and the Ground was "venting," voicing frustration with those on the Ground over barely manageable and unmanageable conditions aboard Mir. However, this communication profile, along with similar profiles from the spaceflight record (including such communication experienced during the Apollo 13 mission), provide data for use in future. What these profiles reveal is the phenomenon of divergence in situation awareness between on orbit crews and their Ground teams. Matching degrees of divergence in situation awareness with numbers of successes and failures on space missions can be useful for future long-duration missions.

Did Tsibliev and Lazutkin employ the predicted countermeasure against stress by demonstrating autonomy from the Ground on their own initiative, as in the Skylab example? The record shows that they sometimes switched off their communication prematurely, as in hanging up the phone on someone that one is not having a satisfactory conversation with. When Jerry Linenger flew with the pair, he had his own "spin" on that technique. He switched off voice communication - but not other communication -- with his Ground team as a means to express his frustration with their performance and awareness of how he perceived his situation. One could say that to some degree the Cohen and Junge model predicted autonomy from the ground as a countermeasure against stress. Mostly, autonomy from the Ground was enforced by the degradation in Russian and American communications infrastructures that previous space flyers (during the Space Race) may not have suffered. The kind of autonomy that the model intended as a countermeasure against stress, as in space flyers having a final "say" over the Ground in a disagreement, did not emerge. As for changes in mission objectives being employed as countermeasures against errors, the main change in mission objective, to evacuate Mir, was never employed.

\section{Territoriality}

Territoriality has been observed on Russian and American space missions. The "ergonomics" created by microgravity conditions and the close quarters can instigate territorial behaviors, as in the case of a space flyer who drew the line of his companions hovering weightless over his food while he was eating. On Salyut 7, Lebedev and Berezevoy found it necessary to have a remedial discussion about considering their mutual equipment in terms of "yours" and "mine." A couple of salient examples obtain from the Mir-NASA experience. Jerry Linenger staked out certain modules and spaces as "his" personal domain. He was most covetous of the exercise equipment. That was because, beyond the benefit of keeping fit on orbit, something that, as a physician, he was more than aware of its necessity, his daily terrestrial routine showed that he was likely enjoying "flow" experiences from vigorous daily exercise. The "runner's high," for example, is a flow experience. When it became necessary to cut Linenger off from exercise to keep carbon dioxide levels down, it was like keeping his drug-of-choice out of reach. Interpreted as something similar to territorial behavior by astronauts were cases when cosmonauts would be ambiguous about certain repairs or procedures that they did not care to discuss, for various reasons, with the astronauts. All of these incidents have caused greater or lesser degrees of aggravation among Russian, American, and mixed crews.

However, there was one instance of territoriality, a case of extreme need for privacy, that no one much minded. While on orbit with astronaut Norm Thagard, Commander Vladimir Dezhurov's mother passed away and he needed "his space." He was said to be especially close to his mother. In his mourning, he disappeared into a module for several days, coaxed to eat and drawn back into the microsociety of Mir by his fellow space flyers. They respected his boundaries to reduce his stress and, little by little, negotiated to bring him back into the fold.

In the case of Linenger's insistence on using the exercise equipment, periods of non-access and reduced access to the equipment had to be imposed to prevent, not only stress to his fellows, but $\mathrm{CO}_{2}$ build-up for all. Only negotiations involving the Ground team seemed to settle the issue.

\section{E. Incompatibilities}

Social and psychological heterogeneity is not synonymous with incompatibility, though there are researchers who still persist in trying to equate the two different phenomena. In fact, heterogeneity in extreme environmental teams, both psychological and sociological, can more easily overcome things, events, and situations that create incompatibility. That is probably because people have a wider "toolkit" to work the problems. And, in isolated and confined environments over long duration, these differences in the crew provide a wealth of interest to each another. However, there is one kind of heterogeneity that is no good, especially when it is of a slapdash nature. Such 
heterogeneities are things like disjointed research programs, different national priorities, and different work regimes that reflect those priorities, and especially where the crew comes into that situation untrained in what to expect.

On Mir, disjointed research programs, different national priorities, and different work regimes reflecting those priorities pinned on the crew caused incompatibilities. Mir was a graphic testbed for this in ways that the Salyuts were not, as guest cosmonauts were expected to toe the line in relation to the host's work regime. On Mir, astronaut crewmates went into the enterprise regarding themselves as partners to their cosmonaut mates.

Root causes like disjointed research programs, different national priorities, and different work regimes can easily be masked by preconceived ideas of optimal and off-nominal personality, cultural, and ethnicity profile mixtures. (Those of us who are psychologists tend to collude in this process. We, of course, want to select-out the psychotics and select-in the people that we think are best suited for missions and their teams.) The difficult thing is to take a larger view and separate the larger socio-politically induced signal from the ambient social and psychological noise. However, this is tough to do. On one hand there is the pressure of politics and money, flogging cosmonauts to try risky docking maneuvers and stop needed station repairs to shoot television commercial footage and forcing astronauts to run as many experiments for corporate sponsors till, either they are run ragged or they withdraw into their own little mission universes that are bounded by an experiments calendar at the expense of what else is going on around them. On the other hand, there is the individual responsibility model that both Russian and American societies subscribe to. That is to say, when something goes wrong, find the individuals responsible and deal with him or her. If something is about to go wrong, expect (or not) the individuals involved to be able to reach inside themselves for resources to build a fortress against larger social forces that would pull them this way and push them that way. Never mind that your crew was thrown into a mission situation that is divided by two different work regimes driven by politics and money, never mind that the social mathematics is not there to find a solution to that overarching problem. Somehow the individual responsibility model expects each person on orbit to find the resources within themselves and among themselves to do magic and make it work! We need to recover from this individual-centric thinking and see the wider social parameters. The best countermeasure against the stress of disjointed research programs, different national priorities, and different work regimes is adequate planning. If there is going to be disjointed research programs, different national priorities and different work regimes, then train the astronauts and cosmonauts to know what to expect and give them some guidelines on how to cope with these things. That way, psychologists will not have to worry so much that someone with a "Don Juan" psychological profile is being teamed with someone with a "Robespierre" profile, and whether or not the other crewmembers with other profiles altogether can serve as intermediaries between the two. Of course, attention to composition is important. But, groups will function better if they are not hobbled by poor planning and paucity of training, regardless of their composition. For, in future, there may come times where circumstances may dictate teaming less-than-optimal crews, sociologically and psychologically.

The Cohen and Junge model predicts that crew selection and crew training would be brought in as countermeasures against stress. However, on the American side, there was not much of an astronaut cadre to choose from in the Mir-NASA selection process. On the Russian side, there was not enough training for those who wound up aboard Mir. Then, on orbit, there was little or nothing in terms of continued training or any sort of group process brought to bear as countermeasures against errors. 
Figure 2.a. Critical Habitability I

\begin{tabular}{|c|c|c|c|c|}
\hline STRESSORS & $\begin{array}{c} \\
\text { COUNTER- } \\
\text { MEASURES } \\
\text { AGAINST } \\
\text { STRESS }\end{array}$ & $\begin{array}{c}\text { DEGRADED } \\
\text { PERFORMANCE }\end{array}$ & $\begin{array}{c}\text { COUNTER- } \\
\text { MEASURES } \\
\text { AGAINST ERRORS }\end{array}$ & $\begin{array}{l}\text { SAFETY } \\
\text { HAZARD }\end{array}$ \\
\hline $\begin{array}{c}\text { Volume } \\
\text { Limitations }\end{array}$ & $\begin{array}{c}\text { Architecture: } \\
\text { Design Privacy, } \\
\text { Windows }\end{array}$ & $\begin{array}{c}\text { Feelings of } \\
\text { Claustrophobia; Lack } \\
\text { of Privacy }\end{array}$ & $\begin{array}{l}\text { Privacy or } \\
\text { Evacuation }\end{array}$ & $\begin{array}{l}\text { Irritability; } \\
\text { Paranoia }\end{array}$ \\
\hline Noise & $\begin{array}{l}\text { Vibration } \\
\text { Isolation and } \\
\text { Control }\end{array}$ & $\begin{array}{l}\text { Sleep Disturbances; } \\
\text { Poor Communication }\end{array}$ & $\begin{array}{c}\text { Earmuffs; } \\
\text { Headsets; Drugs; } \\
\text { Communication } \\
\text { Devices }\end{array}$ & $\begin{array}{c}\text { Failure to } \\
\text { Respond; Failure } \\
\text { to Communicate } \\
\text { or Coordinate }\end{array}$ \\
\hline $\begin{array}{l}\text { Housekeeping (or } \\
\text { Lack Of) }\end{array}$ & $\begin{array}{l}\text { Routines and } \\
\text { Training }\end{array}$ & $\begin{array}{c}\text { Environment Quality; } \\
\text { Deterioration }\end{array}$ & $\begin{array}{c}\text { Assignment of } \\
\text { Responsibilities; } \\
\text { Teamwork }\end{array}$ & $\begin{array}{c}\text { Breakdown in Life } \\
\text { Support }\end{array}$ \\
\hline $\begin{array}{l}\text { Hygiene; } \\
\text { Cleanliness }\end{array}$ & $\begin{array}{l}\text { Personal } \\
\text { Practices; } \\
\text { Training }\end{array}$ & $\begin{array}{l}\text { Discomfort to Others; } \\
\text { Illness; Disease }\end{array}$ & Group Standards & $\begin{array}{l}\text { Personal Illness; } \\
\text { Inability to } \\
\text { Perform Tasks }\end{array}$ \\
\hline
\end{tabular}

\section{F. Volume Limitations}

All the countermeasures against stress that the Cohen and Junge model predicted to mitigate volume limitations were employed aboard Mir. There was a certain degree of privacy, especially when only a crew of three was aboard. There were windows available to look out of. Still these things did not serve as sufficient countermeasures against stress. What seem the largest problems with volume limitations aboard Mir were those of stowage and inconvenient work envelopes in which to make repairs. While garbage could be transferred to Progress vehicles and burnt up upon re-entry to Earth's atmosphere, items left behind by paying guest cosmonauts cluttered the station, taking up space. This only exacerbated the lack of room to work when space flyers needed to reach behind panels to repair dysfunctional hardware, to clean, or to mop up errant fluids.

\section{G. Noise}

Noise was not much of an issue aboard Skylab because of the low air pressure inside that made it necessary for astronauts to shout in close proximity to one another to be heard. Noise did not seem to be an issue aboard Mir. However, it is an issue aboard the ISS with, to wit, astronauts and cosmonauts attempting to apply the countermeasures against stress that the Cohen and Junge model predicts as beneficial: vibration isolation and control.

\section{H. Housekeeping Issues}

There are two different kinds of issues embraced here. One, demands procedures for circumstances when one has, for example, to use a hacksaw on metal. On Salyut 7, an eye injury occurred from metal shavings floating around in the interior following the construction of a needed partition. The second issue involves things like who does what when and who is needed to pitch in to help if needed. The Mir-NASA astronauts had very little training or assignment of responsibilities in either of these categories of housekeeping issues. It appears that they were simply expected to fall into a routine and standards of teamwork would somehow emerge.

\section{Hygiene; Cleanliness}

To wit, space flyers do their best to stay clean with the limited means available. Aboard Mir there was limited facilities and crewmembers used them. However, as long-duration space work increases and crews become larger, this will likely emerge an issue, just as it has in terrestrial polar expeditions. The Cohen and Junge model tracks with the kinds of countermeasures against stress and errors relating to hygiene and cleanliness that commanders of polar expeditions had had to employ. 
Figure 2.b. Critical Habitability II

\begin{tabular}{|c|c|c|c|c|}
\hline STRESSORS & $\begin{array}{c} \\
\text { COUNTER- } \\
\text { MEASURES } \\
\text { AGAINST } \\
\text { STRESS }\end{array}$ & $\begin{array}{c}\text { DEGRADED } \\
\text { PERFORMANCE }\end{array}$ & $\begin{array}{c}4 \\
\text { COUNTER- } \\
\text { MEASURES } \\
\text { AGAINST } \\
\text { ERRORS }\end{array}$ & $\begin{array}{l}\text { SAFETY } \\
\text { HAZARD }\end{array}$ \\
\hline $\begin{array}{l}\text { Thermal/Humidity; } \\
\text { Closed Atmosphere }\end{array}$ & $\begin{array}{l}\text { Environmental } \\
\text { Controls }\end{array}$ & $\begin{array}{l}\text { Discomfort; } \\
\text { Irritability }\end{array}$ & $\begin{array}{l}\text { Air Movement; } \\
\text { Gas Composition } \\
\text { and Control; } \\
\text { Temperature and } \\
\text { Humidity } \\
\text { Control } \\
\end{array}$ & Increased Anxiety \\
\hline $\begin{array}{c}\text { Confinement, } \\
\text { Isolation, Separation }\end{array}$ & $\begin{array}{c}\text { Communication } \\
\text { with Family and } \\
\text { Friends; Visitors; } \\
\text { Social Events; } \\
\text { Recreation; } \\
\text { Counseling; } \\
\text { Architecture } \\
\text { Geometry; } \\
\text { Stowage }\end{array}$ & $\begin{array}{l}\text { Loneliness; Morale } \\
\text { Deterioration; } \\
\text { Impaired } \\
\text { Judgment; } \\
\text { Perception Under } \\
\text { Stress; } \\
\text { Claustrophobia }\end{array}$ & $\begin{array}{l}\text { Group Activities; } \\
\text { Hobbies; } \\
\text { Personal } \\
\text { Interests; } \\
\text { Judgment } \\
\text { Checks; Color } \\
\text { Coding; } \\
\text { Lighting; } \\
\text { Multiple Access, } \\
\text { Mobility Aids }\end{array}$ & $\begin{array}{c}\text { Breakdown in } \\
\text { Group Process; } \\
\text { Teamwork; } \\
\text { Mistakes in } \\
\text { Judgment, } \\
\text { Perception, or } \\
\text { Action; Paranoia }\end{array}$ \\
\hline Artificial Lighting & $\begin{array}{l}\text { Lighting Design; } \\
\text { "Natural Light" }\end{array}$ & $\begin{array}{l}\text { Fatigue, Irritability, } \\
\text { Blurred Vision }\end{array}$ & $\begin{array}{l}\text { Special Task } \\
\text { Lighting }\end{array}$ & Mistaken Perception \\
\hline
\end{tabular}

\section{J. Thermal/Humidity; Closed Atmosphere}

Temperature and humidity control and other vagaries of a closed atmosphere were very salient issues aboard Mir. Environmental controls were not sufficient countermeasures against stress as they were not all functioning optimally. These things had to be dealt with one problem at a time in terms of countermeasures against error, errors that would have not only increased anxiety, but would have led to a great many more safety hazards. All of this was complicated by the Ground not being able to send up enough data about toxicity of ethylene glycol vapors. In addition, there was $\mathrm{CO}_{2}$ build-up to contend with at times. There is some evidence that concern is warranted with heavy concentrations of ordinary industrial gases and compounds in vapor form in closed environments. In the original Biosphere II experiment in the Arizona desert, nitrous oxide levels rose above normal in the closed habitat and may have partially disabled the physician member of the group. As it was, ethylene glycol contact caused a range of irritation in Tsibliev's and Lazutkin's skin and eyes. Worrying about the antifreeze compound getting into their drinking water and about toxicity in vapor form created a good deal of anxiety in Linenger.

\section{K. Confinement, Isolation, Separation}

The concern emerged among psychologists in advance of John Blaha's mission that he would be separated from the usual support persons in his personal environment. So, extra steps were taken that were not inconsistent with Cohen's and Junge's countermeasures against stress and errors. Still, Blaha developed depression, though he seems to have been able to deal with it with internal resources he was supposed not to possess by his psychologists.

One methodological issue (that has a bearing on confinement, isolation, and separation) comes up in digging through chronologically ordered data that can be quantified from extreme environmental expeditions begins with a question: When can the researcher start the clock on examining the mission? In general, such data is properly extracted only when a space mission is launched or when terrestrial explorers get to the regions they intend to explore. However, this methodological issue might be re-considered under certain conditions. That is because another entire category of confinement, isolation, and separation is visible when one considers the entire panorama of the Mir-NASA enterprise. The astronauts' "missions" effectually began before they set foot on Mir. They were separated from the agency infrastructure they had come to rely upon and confined and separated by several factors early on -- like the woefully inadequate crash course in Russian language at the Defense Language Institute. They often did not receive the level of support they were accustomed to because the two host agencies were making up 
their plan of cooperation as they went. John Blaha perhaps said it best when he complained that they were launched already exhausted.

\section{Artificial Lighting}

Mir's lighting situation was dim. The station already having been designed and put on orbit, there was no way to increase illumination through "natural lighting." Special task lighting was available mainly through the aid of penlite-style flashlights that could be gripped between the teeth. Likewise, Soyuz and shuttle pilots were not thrilled about the outside lighting. Of the lessons learned from Mir that were applied to the International Space Station was ample outside illumination near docking ports and other critical external facilities.

Figure 3. Task Related Issues: Task Assignment/Role Definition

\begin{tabular}{|c|c|c|c|c|}
\hline STRESSORS & $\begin{array}{c} \\
\text { COUNTER- } \\
\text { MEASURES } \\
\text { AGAINST } \\
\text { STRESS }\end{array}$ & $\begin{array}{l}\text { DEGRADED } \\
\text { PERFORMANCE }\end{array}$ & $\begin{array}{c}\mid \\
\text { COUNTER- } \\
\text { MEASURES } \\
\text { AGAINST } \\
\text { ERRORS }\end{array}$ & $\begin{array}{l}\text { SAFETY } \\
\text { HAZARD }\end{array}$ \\
\hline $\begin{array}{l}\text { Work Environment } \\
\text { Problems }\end{array}$ & $\begin{array}{c}\text { Station } \\
\text { Organization/De } \\
\text { sign }\end{array}$ & Fatigue Factors & $\begin{array}{l}\text { Work Station } \\
\text { Design }\end{array}$ & $\begin{array}{l}\text { Mistake/Inadvertent } \\
\text { Action }\end{array}$ \\
\hline $\begin{array}{c}\text { Work Organization } \\
\text { Leadership }\end{array}$ & $\begin{array}{l}\text { Leadership } \\
\text { Training; } \\
\text { Consensus }\end{array}$ & $\begin{array}{l}\text { Conflicts with } \\
\text { Leadership }\end{array}$ & $\begin{array}{c}\text { Crisis } \\
\text { Resolution; } \\
\text { Chain of } \\
\text { Command }\end{array}$ & Conflicting Actions \\
\hline Task Assignment & Task Selection & $\begin{array}{l}\text { Monotony; } \\
\text { Boredom }\end{array}$ & Task Rotation & $\begin{array}{c}\text { "Familiarity Breeds } \\
\text { Contempt"; Lack of } \\
\text { Caution }\end{array}$ \\
\hline Physical Limitations & $\begin{array}{l}\text { Crew Selection; } \\
\text { Physical } \\
\text { Endurance }\end{array}$ & $\begin{array}{l}\text { Strain on } \\
\text { Endurance }\end{array}$ & $\begin{array}{c}\text { Mandatory } \\
\text { Physical } \\
\text { Exercise } \\
\text { Regimen }\end{array}$ & $\begin{array}{l}\text { "Cutting Corners"; } \\
\text { Physical Inability to } \\
\text { Perform Tasks }\end{array}$ \\
\hline $\begin{array}{l}\text { Scheduling and } \\
\text { Coordination } \\
\text { Conflicts }\end{array}$ & $\begin{array}{l}\text { Group Activities } \\
\text { and Meetings }\end{array}$ & $\begin{array}{l}\text { Low Morale and } \\
\text { Motivation }\end{array}$ & $\begin{array}{c}\text { Crew/Buddy } \\
\text { Checks and } \\
\text { Drills }\end{array}$ & $\begin{array}{l}\text { Lack of Effective } \\
\text { Crew Interaction }\end{array}$ \\
\hline
\end{tabular}

\section{Work Environment Problems}

The Mir seems to have been designed well overall and there were no complaints about the layout of workstations. Where the problems emerged was in the crowded condition of the station, not being able to move enough equipment out fast enough before another load of gear came in. As a result, things got cached as they could. As mentioned before, this only worsened the issue of tight work envelopes.

\section{N. Work Organization/Leadership}

Consensus is not something that usually is a feature of leadership and work organization when they revolve around a military structure. Though consensus was sometimes used as a countermeasure for stress revolving around work organization and leadership issues among Mir-NASA crews, it was not the first thing that they thought to employ. All the missions appeared to leave wide open the questions to the astronauts: Who's in charge? Under what circumstances is he in charge? What's my role aboard the station? Under what conditions might my role change?

In many cases, astronauts and cosmonauts had some sort of leadership training. The thing is, they did not go through this training together, rather getting it from differing organizations - the Soviet Air Force, the United States Navy, etc. Astronauts who were or had been field-grade military officers, who had flown, and even commanded, prior space missions were sometimes offended when cosmonauts ordered them to "fetch and carry" something aboard the Mir. At other times, they reacted as if they had heard something funny, thinking their cosmonaut fellows were up to some kind of "Mickey Mouse" behavior. So, the leadership training that the astronauts and cosmonauts had was not an effective countermeasure to stress. 
Every astronaut's impression going into the mission was that they were partners in the mission - not guests and certainly not flunkies. They expected to be treated something more akin to brother officers and space flyers than "go-fers." NASA superiors were constantly telling the astronauts to "bond" with the Mir cosmonauts. To some degree, as time went on, Russian space officials told the same thing to the cosmonauts. But, this goal was to greater or lesser degree elusive. One would have thought that the common enemy of the dangers of space or of bureaucratic supervisors would have made them all bosom buddies. Perhaps what bonding did take place was owing to those things.

Of course the obstacles that made stressors of work organization and leadership were the disjointed research programs, different national priorities, and different work regimes reflecting those priorities. Lay on top of that a military structure that opposes consensus and it was a recipe tailor-made to create distrust, paranoia, and conflicting actions among crewmembers.

From military experience and from studying disaster responses and various kinds of extreme environmental expeditions, the author has recommended in reports elsewhere that assignment of task domains take precedent over military ranking systems (Dudley-Rowley 1995; ${ }^{11}$ Dudley-Rowley, Okushi, Gangale, Flores, and Diaz 2003). This is, in fact, and perhaps ironically, the system that works best for elite military units in dangerous venues. In this system there is a place for consensus among the different task-performers who must orchestrate their efforts to accomplish their missions relatively autonomously from bureaucratic supervisors. Military ranking systems are great for martialling the everyday minutiae of large groups of persons toward a plethora of goals in time and space, but these systems are a hindrance to elite small forces performing one-of-a-kind missions in special venues.

Astronauts and cosmonauts sometimes would use the "chain-of-command," named as a countermeasure against errors in the Cohen and Junge model, and would seek out the station commander to resolve a difference of opinion. This was useful. And, it is a pattern that is supported from the expeditionary record, where having someone nominally in charge with some real leadership, negotiation, and adjudication skills upon whom crewmembers can defer and rely in an emergent situation is beneficial.

\section{O. Task Assignments}

Tasks aboard Mir could be categorized as in situ vs. emergent. Astronauts and cosmonauts went to the station with some overall ideas about their in situ tasks in the day-to-day routine. The earlier Mir astronauts expected to perform an agenda of scientific experiments. They were sent to the station with a minute-by-minute plan that was de rigueur for shuttle flights. This was frustrated at the outset when Norm Thagard's full suite of experiments was logistically delayed. Thagard found himself with a lot of time on his hands. So, his tasks followed an emergent pattern, doing what he could to help cosmonauts with their tasks and making use of his recreational package. Shannon Lucid's scientific agenda had been so problematic coming together prior to launch that her ground support team had gone to great lengths to uplink detailed instructions to her on orbit. With so much help, she finished all of her experiments ahead of time, assisted her cosmonaut fellows with whom she seemed to have bonded well, and relaxed with her onboard library. John Blaha's experience was different. He did not have the detailed help that Shannon Lucid had had. His scientific agenda seemed like a never-ending set of experiments aboard a shuttle flight that went on forever and ever. Before he could finish one set of experiments, his ground team called up more. As mentioned before, his Russian commander vigorously protested this treatment. At this point, the cosmonaut crews were themselves attempting to keep to something more like an eight-hour workday on Earth. Repairs had to be made to keep the station running, but those repairs were not on the order of magnitude that the Mir crews would have to contend with later.

When Astronaut Linenger came aboard, his intent was to do all his experiments and try to carve out a livable day of routine. Linenger's terrestrial life was consistently built around a daily routine that was pitched toward accomplishment and physical exercise. When emergent tasks interfered with that, he withdrew more stringently into his routine. When his cosmonaut fellows failed to motivate his full participation in the, by then, constant stream of necessary repairs, his ground team was forced to urge him away from the structure of the in situ agenda. They were only partially successful. Because of the steady stream of repairs that had emerged to keep Mir up and running, the cosmonauts were themselves forced out of their routines that called for a livable workday. They essentially kept working till they dropped. So, the astronaut was forced out of his in situ routine and the cosmonauts were forced out of theirs. Finally, they were kept from bonding as one against the elements and their frustrations against the ground because of the different national agendas. Owing to political and economic realities, Tsibliev and Lazutkin showed a certain degree of reserve in disclosing details of the extent of repairs needed aboard Mir and in the risky docking maneuver that led to a near miss with a Progress supply vessel. Owing to a different set of political and economic realities, Linenger found it easy to insist on continuing his routine while his cosmonaut fellows worked like slaves. Tsibliev, Lazutkin, and Linenger were not "happy campers" with their situations and with each other. Though it was 
different political and economic realities that drove a wedge between astronaut and cosmonauts on this mission, it was the same kind of problem, making them homogenous in their distrust of one another.

As if in response of a "lesson learned," the last three Mir-NASA astronauts focused more on bonding with their cosmonaut teammates and making a point to help with repairs. Michael Foale arrived at the station with no illusions about completing a full suite of experiments for a host of corporate and academic sponsors. He was more interested in bonding with his cosmonaut teammates and helping them with the repairs to the Mir. His unique situation exemplified what the investigators reported on above in regard to heterogeneity. Michael Foale was no stranger to heterogeneous arrangements, the son of an English father and American mother, married to an American wife. While training for his mission in Russia, he and his wife socialized routinely with Russians at Star City, in contrast to those other Americans who chose mainly to socialize with Americans on the NASA team.

Similarly, while in training in Moscow, Dave Wolf, an unmarried astronaut, hooked up with a couple of Russian girlfriends and enjoyed the city's "singles scene." Despite his station commander's irritation with his "space teenager" ways on orbit, he came to cheerfully take orders to help with repairs from his station commander and volunteering for menial chores like mopping up condensate. Feeling a little like a new Army recruit in boot camp made him seem more like part of the team, he later reported.

Andy Thomas, an Australian, the last Mir astronaut, was at first aggravated about his too-small Orlan spacesuit and miffed about the tendency of the press to report just this aspect of his on-orbit life. However, he came to settle in and bond with his cosmonaut teammates. He later reported that the social heterogeneity of language and culture aboard the Mir kept him enthusiastic about life aboard the station over his months on orbit.

It can be especially seen in these last three Mir-NASA missions that astronauts felt free to avail themselves of the countermeasure of taking on emergent repair tasks than their in situ science agenda tasks that they brought to the station. In the long run, this ability to choose to do the emergent tasks, warded against monotony, boredom, contempt, and lack of caution (complacency). Perhaps this is simply owing to the "lessons learned" from other MirNASA astronauts before them, but it is compelling to think that the heterogeneity in their backgrounds that they brought aboard the station increased their ability to engage in emergent tasks, to quickly apprehend changes in situation and related task necessities. That Shannon Lucid also engaged in emergent task on her tour-of-duty could also correlate to the gender heterogeneity she brought aboard and the fact that she had lived abroad in her early life.

\section{P. Physical Limitations}

In the space programs it is conventional wisdom to select crewmembers according to their superior physical endurance in order to obtain a crew who will be less likely to feel strain until upper limits of human endurance are reached. However, the Mir experience taught that selection can only be so useful. Ecological considerations in design of equipment and environment are limiting factors. For example, one potential Mir astronaut was bumped from her tour-of-duty because she was too short, at first for the Orlan spacesuit, and then, later, for related EVA reasons. Andy Thomas was a bit too tall and on-orbit alterations had to be made. If these ecological considerations are recognized in time, then care in crew selection can be exercised. However, as the Mir experience taught, events can occur over the course of the mission that create new ecological considerations. For example, when air-scrubbing systems are compromised or have to be curtailed, then it is not possible to employ a mandatory exercise regimen as a countermeasure to maintain physical condition without raising $\mathrm{CO}_{2}$ levels to dangerous levels.

In planning extended space missions, one simply cannot count too much on the capacities of individual crewmembers alone, but instead one must bank on a comprehensive picture, the components of which are the different human factors interfaces: the human-technology interface, the human-environment interface, and the human-human interface. Then, and only then, can the human individual's physical limitation be assessed better and countermeasures planned accordingly.

\section{Q. Scheduling and Coordination Conflicts}

John Blaha's and Jerry Linenger's missions typified this stressor the best. Commander Korzun employed a version of the countermeasure of "group activities and meetings" in the Cohen and Junge model when Astronaut Blaha was continued to be overloaded by his ground team. As described above, he "pulled rank" as the Mir's master during a communication period with the ground, addressing the Americans in the TsUP on the ground in a public way, and in front of Astronaut Blaha, telling them that he did not want his astronaut crewman abused any longer. Commander Korzun's countermeasure worked. John Blaha's load was reduced. While Astronaut Blaha's morale overall was low during his mission, it was boosted above what it might have been by his station commander's intercession.

During Astronaut Linenger's mission, his crew was not able to gain his full participation in the emergent schedule, which was demoralizing and demotivating to Tsibliev and Lazutkin. They seem to have invented their 
own countermeasures to their own stress by employing Kukla-esque joking over an open microphone to the TsUP about Linenger's routines making them seem like second-class citizens. Owing to the change in their in situ routine because of emergent realities, Commander Tsibliev employed a good bit of venting at the ground. Not unusual, as this countermeasure has been seen before in earlier space ventures on both American and Russian sides. Not only does it allow space flyers to "let off steam," but sometimes they are able to override the wishes of the ground in this manner.

As Astronaut Linenger came to adhere more and more to his own mission agenda as his countermeasure against the emergent situation that was creating such scheduling and coordination conflicts, Tsibliev and Lazutkin saw fit to countermeasure against potential error by checking up on Astronaut Linenger to see what he was doing all by himself away from them This was a form of "buddy check" predicted by the Cohen and Junge model. Whether or not it was a real countermeasure against error on this mission is debatable, but it had the effect of putting the cosmonauts' minds to rest, reducing their stress.

\section{Figure 4. Crew Incapacitation}

\begin{tabular}{|c|c|c|c|c|}
\hline STRESSORS & $\begin{array}{c}4 \\
\text { COUNTER- } \\
\text { MEASURES } \\
\text { AGAINST } \\
\text { STRESS }\end{array}$ & $\begin{array}{l}\text { DEGRADED } \\
\text { PERFORMANCE }\end{array}$ & $\begin{array}{c}\text { A } \\
\text { COUNTER- } \\
\text { MEASURES } \\
\text { AGAINST } \\
\text { ERRORS }\end{array}$ & $\begin{array}{l}\text { SAFETY } \\
\text { HAZARD }\end{array}$ \\
\hline $\begin{array}{c}\text { Space Sickness; } \\
\text { Gas Bubbles in } \\
\text { Water }\end{array}$ & $\begin{array}{c}\text { Selection; } \\
\text { Adjustment; } \\
\text { Maintain/Check } \\
\text { Water System }\end{array}$ & $\begin{array}{c}\text { Poor Task } \\
\text { Performance; Gas } \\
\text { Pains }\end{array}$ & $\begin{array}{c}\text { Treatment; } \\
\text { Improve Water } \\
\text { System }\end{array}$ & $\begin{array}{l}\text { Crew Failures to } \\
\text { Respond }\end{array}$ \\
\hline Illness & $\begin{array}{l}\text { Examinations } \\
\text { and Health } \\
\text { Maintenance } \\
\text { Program }\end{array}$ & $\begin{array}{l}\text { Short Term } \\
\text { Incapacitation }\end{array}$ & Treatment & Contagion? \\
\hline Injury & $\begin{array}{l}\text { Space Industrial } \\
\text { Safety }\end{array}$ & $\begin{array}{l}\text { Long Term } \\
\text { Incapacitation }\end{array}$ & $\begin{array}{l}\text { Return to Earth? } \\
\text { Stabilize on } \\
\text { Orbit? }\end{array}$ & $\begin{array}{l}\text { Distraction of Other } \\
\text { Crew Members }\end{array}$ \\
\hline $\begin{array}{c}\text { Emotional/Mental } \\
\text { Problem }\end{array}$ & $\begin{array}{l}\text { Crew Selection } \\
\text { and Training }\end{array}$ & $\begin{array}{c}\text { Lack of Trust and } \\
\text { Cooperation }\end{array}$ & Relief from Duty & $\begin{array}{l}\text { Abnormal Behavior; } \\
\text { Detrimental Actions }\end{array}$ \\
\hline $\begin{array}{l}\text { Failure in Life } \\
\text { Support System }\end{array}$ & $\begin{array}{c}\text { Abandon, } \\
\text { Evacuate One } \\
\text { Module }\end{array}$ & $\begin{array}{l}\text { Confinement, } \\
\text { Trauma }\end{array}$ & $\begin{array}{c}\text { Repairs, } \\
\text { Replacement }\end{array}$ & $\begin{array}{l}\text { Loss of Access to } \\
\text { Critical Functions }\end{array}$ \\
\hline $\begin{array}{l}\text { Death of Crew, } \\
\text { Family or Friend }\end{array}$ & Counseling & $\begin{array}{l}\text { Trauma to Crew; } \\
\text { Disruption of } \\
\text { Teamwork }\end{array}$ & Counseling & $\begin{array}{l}\text { Preservation or } \\
\text { Disposal of Body; } \\
\text { Inability to Work }\end{array}$ \\
\hline
\end{tabular}

\section{R. Space Sickness; Gas Bubbles in Water}

Space Adaptation Sickness (SAS) and incidents of air bubbles in the water system are not unusual occurrences on space missions. Crew selection against SAS is not an especially helpful countermeasure, and, in any event, the condition tends to pass after a few days in space. Maintenance checks and repairs have successfully countermeasured against air bubbles in water systems on those space missions that have reported them.

\section{S. Illness}

Those on both sides, Russian and American, have seen as excessive Astronaut Linenger's concern that ethylene glycol would get into the Mir water supply or that there might be health dangers from breathing ethylene glycol vapors. However, his concern was warranted from his experience with environmental medicine and in his and his cosmonaut fellows' firsthand experience with working around the coolant. Exposure to ethylene glycol was an irritant to eyes and skin. Some of the coolant did find its way into their water system. Ingesting enough ethylene glycol can lead to death. While the crew did not ingest enough to suffer such a fate, there was a certain degree of short-term incapacitation owing to eye irritation on the part of the cosmonauts. Surprisingly, consulting NASA toxicologists, they were not able to find much about the toxicity of ethylene glycol vapors. One could say, that Dr. 
Linenger was a one-man countermeasure against this stressor, inasmuch as he could be. For, to make matters worse, not much was available in the form of treatment. More was known about $\mathrm{CO}_{2}$ levels, and, at times, there was enough carbon dioxide present to cause vicious headaches among the crew.

The issue of ethylene glycol aboard the Mir is very similar to the rise in levels of nitrous oxide in the Biosphere II habitat in the Arizona desert that the first crew there experienced. Dr. Roy Walford, the crew's physician in containment with them, attributed nerve damage in his legs that partially lamed him to the high levels of the gas. Similarly, Jerry Linenger attributed a terrestrial bout of pneumonia to the ethylene glycol vapors he breathed in aboard the Mir over such a long period of time. In an attempt to find out about the rising levels of the nitrous oxide, Dr. Walford was not able to find any studies that addressed the health threat, foreshadowing Linenger's experience with ethylene glycol.

\section{T. Injury}

In addition to the illnesses caused by the ethylene glycol and the $\mathrm{CO}_{2}$ levels, the most immediate chance for serious injury was the dangers of suffocation and decompression. Had Tsibliev, Lazutkin, and Foale not been able to seal off the decompressed module fast enough following the collision with the Progress vehicle, they might have died. On the following mission, Cosmonaut Vinogradov experienced a leak in his suit effecting repairs to the station and might have suffocated had that not been mitigated rapidly enough. The Cohen and Junge model calls for countermeasures that adhere to space industrial safety guidelines. Those countermeasures would likely work to offset space accidents. However, guidelines that the Soviet space program had created for conditions under which to operate equipment and to evacuate the station were not followed. To use an aerospace term, the Russians who were later in charge of Mir "pressed the envelope," in order to keep Mir functioning at any cost. However, to be noted, Americans cannot point the finger without pointing it at themselves. How well did the space shuttle Columbia's managers follow safety guidelines that had been set up by those who had gone before? At least Mir's crews and managers were able to stabilize the station's situation on orbit. Columbia's managers chose to downplay the severity of warnings about wing damage, so did not arrive at the chance to offset the disaster on orbit.

\section{U. Emotional/Mental Problems}

This is one of the primary issues of long-duration spaceflight along with kidney stone formation. Yet, it is an area that is still greatly understudied and one that is only partly countermeasured against by crew selection and training. Among other things, the events of a microsociety on an extended mission, even a simulated mission, take on a different meaning for the crew in containment and/or isolation that comes to substantially differ from the experience of the ground team (Dudley-Rowley, Bishop, Farry, and Gangale, 2000; Dudley-Rowley, Whitney, Bishop, Caldwell, and Nolan, 2001).

John Blaha's depression is a case in point. Blaha was the veteran of several space missions prior to his Mir tourof-duty, and had even been in command previously. By the conventional wisdom, there should not have been a problem. Even so, psychologists on both American and Russian sides had serious reservations about his ability to weather long-duration flight. And, that he did experience depression was a testament to their psychological insights. Still, with his depression, Blaha was an abler crewmember than expected.

The effect of the strain of emergent chores, the change in cosmonaut routine from workaday to something more resembling a state of siege certainly wore on Commander Tsibliev. The withdrawals of Astronaut Linenger and Commander Dezhurov, though different in cause and character, gave cause for concern. In no case was the countermeasure against errors, relief from duty, employed. There was too much of a political and economic nature at stake. These men were relieved from duty only when the next flight retrieved them as scheduled.

\section{Failure in Life Support System}

Discussed above was the very real danger of suffocation and decompression during Mike Foale's tour-of-duty. The crew did take the countermeasure of evacuating and sealing off the affected module. Another crew that served with Foale made enough repairs to increase the station's functioning, though the station was not quite again the same as before the collision with the Progress.

\section{W. Death of Crew, Family, or Friend}

No one has yet died on orbit, so no crew has been faced with preservation or disposal of the body of their fellow crewmate. However, judging from the reaction of Commander Dezhurov to the death of his mother on orbit and to the reactions of a couple of the astronauts in training at Star City who had family emergencies back in the United States, reactions that will require counseling can be expected. As in the Dezhurov example, the first round of counseling will likely come from one's own fellows on the mission. 
Figure 5. Personal Choice

\begin{tabular}{|c|c|c|c|c|}
\hline STRESSORS & $\begin{array}{c} \\
\text { COUNTER- } \\
\text { MEASURES } \\
\text { AGAINST } \\
\text { STRESS }\end{array}$ & $\begin{array}{c}\text { DEGRADED } \\
\text { PERFORMANCE }\end{array}$ & \begin{tabular}{c}
\multicolumn{1}{|c}{} \\
COUNTER- \\
MEASURES \\
AGAINST \\
ERRORS
\end{tabular} & $\begin{array}{l}\text { SAFETY } \\
\text { HAZARD }\end{array}$ \\
\hline $\begin{array}{l}\text { Cooking/Eating } \\
\text { Habits } \\
\text { (Restrictions) }\end{array}$ & $\begin{array}{l}\text { Shared Meals; } \\
\text { Accommodation } \\
\text { for Individual } \\
\text { Crew Preference }\end{array}$ & Irritation, Depression & $\begin{array}{c}\text { Adequate } \\
\text { Training }\end{array}$ & $\begin{array}{l}\text { Fire, Odors, } \\
\text { Outgassing }\end{array}$ \\
\hline $\begin{array}{l}\text { Individual Property } \\
\text { (Restrictions) }\end{array}$ & $\begin{array}{c}\text { Education; } \\
\text { Monitoring and } \\
\text { Control; Crew } \\
\text { Training } \\
\end{array}$ & $\begin{array}{l}\text { Personal Autonomy } \\
\text { Diminished; Low } \\
\text { Morale }\end{array}$ & $\begin{array}{l}\text { Monitoring and } \\
\text { Control }\end{array}$ & $\begin{array}{l}\text { Outgassing, } \\
\text { Contamination, } \\
\text { Flammability }\end{array}$ \\
\hline $\begin{array}{l}\text { Boredom, } \\
\text { Monotony }\end{array}$ & $\begin{array}{c}\text { Entertainment; } \\
\text { Crew-selected } \\
\text { Activities }\end{array}$ & Lack of Vigilance & $\begin{array}{c}\text { Adequate Crew } \\
\text { Activities; } \\
\text { Planning and } \\
\text { Scheduling }\end{array}$ & $\begin{array}{l}\text { Practical Jokes, } \\
\text { Distraction, } \\
\text { Accidents }\end{array}$ \\
\hline Clothing & $\begin{array}{c}\text { Variety, } \\
\text { Laundry, Crew } \\
\text { Preference }\end{array}$ & $\begin{array}{c}\text { Irritation, } \\
\text { Discomfort, Less } \\
\text { Personal Freedom }\end{array}$ & Clean Filters & $\begin{array}{l}\text { Lint Problem, } \\
\text { Contamination, } \\
\text { Fire }\end{array}$ \\
\hline $\begin{array}{l}\text { Personal Habits: } \\
\text { Alcohol, Drugs }\end{array}$ & $\begin{array}{l}\text { Crew Selection, } \\
\text { Crew Training }\end{array}$ & $\begin{array}{c}\text { Effects of Overuse; } \\
\text { Withdrawal } \\
\text { Symptoms }\end{array}$ & $\begin{array}{l}\text { Counseling; } \\
\text { Evacuation }\end{array}$ & $\begin{array}{l}\text { Fire; Impaired } \\
\text { Judgement }\end{array}$ \\
\hline
\end{tabular}

\section{Cooking/Eating Habits (Restrictions)}

The modelers were warranted in thinking that food, cooking, and eating might become stressors. Everything surrounding food has been an issue on polar expeditions. The different cooking habits of scientists-explorers on an Antarctic expedition of the 1950s were such an aggravation to the members of the expedition that the U.S. Navy had to send out a military cook. Misuse and abuse of cooking equipment have been a life support concern on such expeditions. Hoarding seems to have occurred on every polar expedition on record. Food seems to take on an importance on long-duration polar expeditions that some other form of gratification enjoys in the workaday world, like money, sex, and drugs. In any event, the prefabricated nature of foodstuffs in space has prevented crewmembers from irritating their crewmates overmuch with making too much of a mess. The worst case from the Mir-NASA missions seems to have been Dave Wolf's misapprehension in how a container of black currant jelly should be opened, that created a bit of a mess. The typical food incident that occurs on space missions is eating something that one is not supposed to eat. Lebedev and Berezevoy on Salyut 7 ate onions that were meant for an agricultural experiment. One can perhaps look the other way when one considers that the men may have been craving "freshies" (fresh vegetables), and that the dulled palate that space flyers experience dictated they eat something spicy. Probably more than one astronaut or cosmonaut has consumed foodstuffs meant for television commercials. Jerry Linenger, expecting pretzels to be sent up to him, almost ate the pretzel bag prop that was needed for the Rold Gold commercial.

Another issue on more of a serious note are the resentments that could accrue owing to those who take coffee, tea, or meal breaks while others are working furiously when life support is at stake. Other resentments could occur if the crew cannot eat at the same times together or if someone who wants to dine alone cannot. In these more serious cases, the Cohen and Junge countermeasures are appropriate. As the volume and variety of people living and working together in space increase, we may expect different personal and cultural cuisines and regulations to pose problems.

\section{Y. Individual Property (Restrictions)}

Discussed before have been incidents where space flyers co-opt a communal piece of equipment for their own. In terms of individual property and its restriction, a number of other cases can be examined. All the astronauts and 
cosmonauts appear to have been allowed a certain amount of personal recreational and leisure items (i.e., books, musical instruments, music tapes, movies, etc.). Sometimes they find that the ground team has slipped them some extra things on board, like the bottles of alcohol that Jerry Linenger found in the sleeves of his spacesuit. So far, crewmates have shown good commonsense in not encroaching on each other's individual's items and sharing them where appropriate. However, should incidents of infringement occur, as often happens among soldiers in garrison, space agencies would likely institute educational programs. Space station commanders might have to start monitoring the stocks of personal items.

\section{Z. Boredom, Monotony}

Boredom and monotony was an issue aboard Salyut 7. Cosmonauts were overjoyed to receive a Progress supply ship, but get irritated in turn when they found the vessel packed in such a way that they had to offload everything over the next several hours to find any items that might entertain them. Boredom and monotony was definitely a concern aboard Mir after Norm Thagard's full suite of scientific gear did not arrive with him on orbit. His recreational and leisure package appeared to be an appropriate countermeasure, as was Shannon Lucid's after she completed her scientific duties. However, as tasks emerged with a bearing on the functionality of the station, while there might have been monotony in the routine of repair (the endless mopping up of condensate, for example), there seemed to be little unfilled time for boredom. Boredom and monotony are companions of extreme environmental venues where the crews do not have enough to do, where there is a paucity of leisure and recreation avenues, and where architectural design is not used as an opportunity to alleviate monotonous surroundings.

\section{AA. Clothing}

In terms of clothing on board Mir, there seemed to be few complaints. The astronauts and cosmonauts wore comfortable outfits that did not bow to fashion and which they wore till the clothing was too dirty to stand. Then, they threw that outfit into the trash and put on another because not much existed in terms of an onboard laundry. So, there was not much stress to countermeasure against. However, lint from fabrics was a problem, being an inch-thick on air filters, Jerry Linenger reported. Part of the repair and maintenance duties was cleaning the air filters. So, space flyers took the appropriate countermeasure against errors that would lead to safety hazards.

\section{BB. Personal Habits: Alcohol, Drugs, Etc.}

Though alcohol was aboard in a limited supply, alcohol and drugs did not seem to be an issue aboard Mir. Sleep drugs were prescribed by ground doctors to help Commander Tsibliev sleep during one long stint when the stress of emergent work overload interfered with his cycle. There is no indication that anyone misused drugs from the medical stores. Perhaps the closest things to annoying personal habits might have been contrary use of the toilet that made waste disposal difficult for others or the music selections of someone that got on others' nerves. Crew selection obviously countermeasured against any alcoholics and drug addicts being aboard Mir. Crew training emphasized toileting procedures. No countermeasures against error for this stressor had to be taken.

\section{Discussion and Conclusion}

So, how predictive was the Cohen and Junge model? Too little quantification of the model exists as yet to say that it was $80 \%$ predictive, for example. However, on a scale of poor, fair, good, and excellent, one could say that it was a good predictor. What has come out of this study are ways that the model can be modified from the Mir experience for use in countermeasuring against stressors aboard the International Space Station and on long-duration space missions. Most of the modifications of the model are in expansion of the countermeasures against stress and those against errors, and also in terms of the safety hazards.

In regard to those stressors exacerbated by varying degrees of autonomy from the ground, some formal protocols need to be formulated that give the crew a wider latitude and last word on scheduling issues and in terms of disagreements with ground. The term "autonomy from ground" should mean more than simply cutting off communications with the ground. In terms of family problems, counseling needs to be also a countermeasure against stress, as well as against errors. This issue of family problems can be expected to become more salient as tours-ofduty in space become longer in duration. Family problems are a normal part of life and are mitigated better when an open avenue is available for people to express themselves. In issues of territoriality, negotiations need to be also included as a countermeasure against stress. In issues of incompatibility, training in group processes should be also a countermeasure against stress, as well as against errors.

In regard to those issues identified under Critical Habitability I stressors, more countermeasures against stress need to be added in response to volume limitations. These additions are 1) mitigating the problem of stowage of 
items brought aboard by guest astronauts and cosmonauts and 2) the design of sufficient work envelopes to get at potential areas of repair. In the area of housekeeping, assignment of responsibilities and teamwork should be countermeasures against stress, as well as against errors.

In regard to those issues identified under Critical Habitability II stressors, in the problems of the closed atmosphere, countermeasures need to be devised against errors when environmental controls are inadequate. The safety hazards extend beyond increased anxiety. When environmental controls are inadequate, there are toxicity concerns, the threat of heat prostration or cold injury, and that of suffocation. In terms of confinement, isolation, and separation, as well as a number of other stressors named in the Cohen and Junge model, reliable communications need to be guaranteed as much as possible. During the Mir-NASA missions, an American engineer figured out how to make communications more reliable between ground and the Mir. Other engineers from NASA obfuscated his efforts to make the communications more reliable, a good example of wrong-headed group-think. Safety hazards that pertain to confinement, isolation, and separation include mental depression. Reliable communications would go far to offset several safety hazards instigated by a number of stressors.

In regard to those items identified under task-related issues, more countermeasures for stress and for errors need to ward against "rat-packing," keeping materiel and equipment aboard from past guest astronauts and cosmonauts that are not essential. In terms of task assignment, there needs to be a dominance of the task-assignment model over the military rank model overall. Countermeasures against stress for task assignment should include task alternatives inasmuch as possible. However, when tasks emerge, as in situations where life support might be at stake, all crew need to play some part. As a countermeasure against error, task rotation might not be possible. In terms of physical limitations of crew, countermeasures against stress should take into account ecological considerations in design and environment. Physical exercise might not be a viable countermeasure against errors because of $\mathrm{CO}_{2}$ build-up and similar conditions. In terms of scheduling and coordination conflicts, allowing for more in-flight coordination among the crewmembers would be more beneficial. Provision for onboard training in advance of more complex tasks would also make coordination less stressful and error-free.

In regard to those items identified under crew incapacitation, a primary countermeasure against stress would be to make the appropriate health effect studies on materials, fluids, and gases that are used in space vessel construction and that emerge during its operation. Organizations that send space flyers on missions should formulate common standards for space industrial safety and then adhere to them in terms of when to return a crew and when to effect repairs in space. Otherwise, other factors like national honor or "group-think" gains a decisive chokehold over the commonsense of engineering. The list of safety hazards go beyond just the distraction of other crewmembers after the injury of a teammate, treading into the realm of the possibilities for injury and death of all the crew. In terms of emotional and mental problems, the primary countermeasures against stress and errors would be for space organizations to catch up on the necessary studies. Counseling in various forms should be considered as countermeasures throughout the lifespan of the mission. Relief from duty may not be an option as experience has taught. Countermeasuring against failure of life support systems could be improved by providing, inasmuch as possible, regular maintenance of those systems and provision of back-up components key to the functioning of those systems. In the event of psychological trauma from death of a crewmate, a family member, or friend, the crew could benefit from some training in counseling in order to know how to respond as a countermeasure against stress. Counseling from other professionals should be available over the lifespan of a mission, another compelling reason for the improvement of reliable communications.

In regard to those items identified under personal choice, more variety in food choices would improve the countermeasures against stress, as well as adequate training in food preparation systems. This list of safety hazards that relate to issues of individual property should include irritation, conflict, and feelings of infringement on individual expression by others. Boredom and monotony as a stressor can be countermeasured against by attention to architectural design. The list of personal habits as stressors should be expanded to include things like the contrary use of toilet facilities and music that others might find irritating. Counseling should be made available over the lifespan of the mission for not only those who develop harmful personal habits, but for those who become annoyed by them. The list of safety hazards should be expanded to include conflict and abnormal behaviors. Figures 6a-f depict the Cohen and Junge model innovated from the Mir experience, new additions in non-bold lettering.

The next step in modifying this model as a useful instrument is to provide it more quantitative vigor. One question emerges for the investigators to resolve: How do we deal with the fact that a behavior or an event can be viewed as a stressor over different parts of the model, both a matter of critical habitability and tasking, for instance? In such a case, which countermeasures take precedent? The authors of the Human Factors Interaction Model wrote about a system of weighting the various stressors and countermeasures in order to evaluate their relative importance. Future research might consider weighting stressors according to a severity index where destruction of all hands would be the worst-case value. Similarly, weighting countermeasures according to an efficacy index could value the 
immediate reversal of the stressor as the best-case value. It would also seem prudent to follow up on Cohen's and Junge's original recommendation that weighting should take into account mission interval (i.e., beginning, middle, end) and its role in the severity of stressors and efficacy of countermeasures in order to look for any short- and longterm patterns of stressors and countermeasures in time.

Figure 6.a. Protocols

(Stressors exacerbated by varying degrees of autonomy from ground)

\begin{tabular}{|c|c|c|c|c|}
\hline STRESSORS & $\begin{array}{c} \\
\text { COUNTER- } \\
\text { MEASURES } \\
\text { AGAINST } \\
\text { STRESS }\end{array}$ & $\begin{array}{c}\text { DEGRADED } \\
\text { PERFORMANCE }\end{array}$ & $\begin{array}{c}\text { † } \\
\text { COUNTER- } \\
\text { MEASURES } \\
\text { AGAINST } \\
\text { ERRORS }\end{array}$ & $\begin{array}{l}\text { SAFETY } \\
\text { HAZARD }\end{array}$ \\
\hline $\begin{array}{l}\text { Scheduling } \\
\text { Overload }\end{array}$ & $\begin{array}{c}\text { Scheduling } \\
\text { Changes; Crew } \\
\text { Rotation; } \\
\text { Crew- } \\
\text { autonomous } \\
\text { Protocols } \\
\end{array}$ & Scheduling Conflict & $\begin{array}{c}\text { Daily } \\
\text { Scheduling; Staff } \\
\text { Meetings; } \\
\text { Reiteration of } \\
\text { Crew-autonomous } \\
\text { Protocols } \\
\end{array}$ & $\begin{array}{c}\text { Lack of } \\
\text { Coordination; } \\
\text { Misunderstanding }\end{array}$ \\
\hline Family Problems & $\begin{array}{c}\text { Family } \\
\text { Interaction; } \\
\text { Secure } \\
\text { Communicatio } \\
\text { ns; } \\
\text { Counseling } \\
\end{array}$ & $\begin{array}{c}\text { Abnormal Behavior; } \\
\text { Depression }\end{array}$ & $\begin{array}{l}\text { Discipline; } \\
\text { Counseling }\end{array}$ & $\begin{array}{c}\text { Deliberate } \\
\text { Conflict; Inability } \\
\text { to Work }\end{array}$ \\
\hline $\begin{array}{l}\text { Disagreements } \\
\text { with Ground } \\
\text { Control }\end{array}$ & $\begin{array}{c}\text { Autonomy } \\
\text { from Ground; } \\
\text { Crew- } \\
\text { autonomous } \\
\text { Protocols }\end{array}$ & $\begin{array}{l}\text { Conflicting } \\
\text { Objectives }\end{array}$ & $\begin{array}{c}\text { Changes in } \\
\text { Mission } \\
\text { Objectives; } \\
\text { Reiteration of } \\
\text { Crew-autonomous } \\
\text { Protocols }\end{array}$ & $\begin{array}{c}\text { Violation of } \\
\text { Safety Criterion }\end{array}$ \\
\hline Territoriality & $\begin{array}{c}\text { Access/Non- } \\
\text { access; } \\
\text { Negotiations }\end{array}$ & Turf Conflicts & Negotiations & $\begin{array}{c}\text { Improper Entry } \\
\text { or Inadequate } \\
\text { Access }\end{array}$ \\
\hline Incompatibilities & $\begin{array}{l}\text { Crew Selection; } \\
\text { Crew Training; } \\
\text { Training in } \\
\text { Group Processes }\end{array}$ & Incompatibilities & $\begin{array}{l}\text { Training; Group } \\
\text { Process; } \\
\text { Training in } \\
\text { group processes; } \\
\text { Training in Group } \\
\text { Processes }\end{array}$ & $\begin{array}{c}\text { Lack of } \\
\text { Cooperation }\end{array}$ \\
\hline
\end{tabular}


Figure 6.b. Critical Habitability I

\begin{tabular}{|c|c|c|c|c|}
\hline STRESSORS & $\begin{array}{c} \\
\text { COUNTER- } \\
\text { MEASURES } \\
\text { AGAINST } \\
\text { STRESS }\end{array}$ & $\begin{array}{c}\text { DEGRADED } \\
\text { PERFORMANCE }\end{array}$ & $\begin{array}{c}\text { A } \\
\text { COUNTER- } \\
\text { MEASURES } \\
\text { AGAINST } \\
\text { ERRORS }\end{array}$ & $\begin{array}{l}\text { SAFETY } \\
\text { HAZARD }\end{array}$ \\
\hline $\begin{array}{c}\text { Volume } \\
\text { Limitations }\end{array}$ & $\begin{array}{c}\text { Architecture: } \\
\text { Design Privacy, } \\
\text { Windows; } \\
\text { Stowage } \\
\text { Mitigation; } \\
\text { Design of } \\
\text { Sufficient Work } \\
\text { Envelopes } \\
\end{array}$ & $\begin{array}{c}\text { Feelings of } \\
\text { Claustrophobia; } \\
\text { Lack of Privacy }\end{array}$ & $\begin{array}{c}\text { Privacy or } \\
\text { Evacuation }\end{array}$ & $\begin{array}{l}\text { Irritability; } \\
\text { Paranoia }\end{array}$ \\
\hline Noise & $\begin{array}{c}\text { Vibration } \\
\text { Isolation and } \\
\text { Control }\end{array}$ & $\begin{array}{c}\text { Sleep Disturbances; } \\
\text { Poor } \\
\text { Communication }\end{array}$ & $\begin{array}{c}\text { Earmuffs; } \\
\text { Headsets; Drugs; } \\
\text { Communication } \\
\text { Devices }\end{array}$ & $\begin{array}{c}\text { Failure to } \\
\text { Respond; Failure } \\
\text { to Communicate } \\
\text { or Coordinate }\end{array}$ \\
\hline $\begin{array}{l}\text { Housekeeping (or } \\
\text { Lack Of) }\end{array}$ & $\begin{array}{l}\text { Routines and } \\
\text { Training; } \\
\text { Assignment of } \\
\text { Responsibilities; } \\
\text { Teamwork }\end{array}$ & $\begin{array}{l}\text { Environment Quality; } \\
\text { Deterioration }\end{array}$ & $\begin{array}{l}\text { Assignment of } \\
\text { Responsibilities; } \\
\text { Teamwork }\end{array}$ & $\begin{array}{l}\text { Breakdown in Life } \\
\text { Support }\end{array}$ \\
\hline $\begin{array}{l}\text { Hygiene; } \\
\text { Cleanliness }\end{array}$ & $\begin{array}{l}\text { Personal } \\
\text { Practices; } \\
\text { Training }\end{array}$ & $\begin{array}{l}\text { Discomfort to Others; } \\
\text { Illness; Disease }\end{array}$ & Group Standards & $\begin{array}{lr}\text { Personal Illness; } \\
\text { Inability } & \text { to } \\
\text { Perform Tasks }\end{array}$ \\
\hline
\end{tabular}


Figure 6.c. Critical Habitability II

\begin{tabular}{|c|c|c|c|c|}
\hline STRESSORS & $\begin{array}{c} \\
\text { COUNTER- } \\
\text { MEASURES } \\
\text { AGAINST } \\
\text { STRESS }\end{array}$ & $\begin{array}{c}\text { DEGRADED } \\
\text { PERFORMANCE }\end{array}$ & $\begin{array}{c}\text { COUNTER- } \\
\text { MEASURES } \\
\text { AGAINST } \\
\text { ERRORS }\end{array}$ & $\begin{array}{c}\text { SAFETY } \\
\text { HAZARD }\end{array}$ \\
\hline $\begin{array}{l}\text { Thermal/Humidity; } \\
\text { Closed Atmosphere }\end{array}$ & $\begin{array}{c}\text { Environmental } \\
\text { Controls }\end{array}$ & $\begin{array}{l}\text { Discomfort; } \\
\text { Irritability }\end{array}$ & $\begin{array}{c}\text { Air Movement; } \\
\text { Gas } \\
\text { Composition } \\
\text { and Control; } \\
\text { Temperature } \\
\text { and Humidity } \\
\text { Control; } \\
\text { Mitigation } \\
\text { Against } \\
\text { Inadequate } \\
\text { Environmental } \\
\text { Controls }\end{array}$ & $\begin{array}{l}\text { Increased Anxiety; } \\
\text { Toxicity Concerns; } \\
\text { Threat of Heat } \\
\text { Prostration; Cold } \\
\text { Injury; Suffocation }\end{array}$ \\
\hline $\begin{array}{c}\text { Confinement, } \\
\text { Isolation, } \\
\text { Separation }\end{array}$ & $\begin{array}{c}\text { Reliable } \\
\text { Communication } \\
\text { with Family and } \\
\text { Friends; } \\
\text { Visitors; Social } \\
\text { Events; } \\
\text { Recreation; } \\
\text { Counseling; } \\
\text { Architecture } \\
\text { Geometry; } \\
\text { Stowage }\end{array}$ & $\begin{array}{c}\text { Loneliness; } \\
\text { Morale } \\
\text { Deterioration; } \\
\text { Impaired } \\
\text { Judgment; } \\
\text { Perception Under } \\
\text { Stress; } \\
\text { Claustrophobia }\end{array}$ & $\begin{array}{c}\text { Group } \\
\text { Activities; } \\
\text { Hobbies; } \\
\text { Personal } \\
\text { Interests; } \\
\text { Judgment } \\
\text { Checks; Color } \\
\text { Coding; } \\
\text { Lighting; } \\
\text { Multiple Access, } \\
\text { Mobility Aids }\end{array}$ & $\begin{array}{c}\text { Breakdown in } \\
\text { Group Process; } \\
\text { Teamwork; } \\
\text { Mistakes in } \\
\text { Judgment, } \\
\text { Perception, or } \\
\text { Action; Paranoia; } \\
\text { Depression }\end{array}$ \\
\hline Artificial Lighting & $\begin{array}{c}\text { Lighting } \\
\text { Design; } \\
\text { "Natural Light" }\end{array}$ & $\begin{array}{c}\text { Fatigue, } \\
\text { Irritability, } \\
\text { Blurred Vision }\end{array}$ & $\begin{array}{c}\text { Special Task } \\
\text { Lighting }\end{array}$ & $\begin{array}{l}\text { Mistaken } \\
\text { Perception }\end{array}$ \\
\hline
\end{tabular}


Figure 6.d. Task Related Issues: Task Assignment/Role Definition

\begin{tabular}{|c|c|c|c|c|}
\hline STRESSORS & $\begin{array}{c}\text { COUNTER- } \\
\text { MEASURES } \\
\text { AGAINST } \\
\text { STRESS }\end{array}$ & $\begin{array}{c}\text { DEGRADED } \\
\text { PERFORMANCE }\end{array}$ & $\begin{array}{c} \\
\text { COUNTER- } \\
\text { MEASURES } \\
\text { AGAINST } \\
\text { ERRORS }\end{array}$ & $\begin{array}{c}\text { SAFETY } \\
\text { HAZARD }\end{array}$ \\
\hline $\begin{array}{c}\text { Work Environment } \\
\text { Problems }\end{array}$ & $\begin{array}{c}\text { Station } \\
\text { Organization/ } \\
\text { Design; "Rat- } \\
\text { packing" } \\
\text { Mitigation }\end{array}$ & Fatigue Factors & $\begin{array}{c}\text { Work Station } \\
\text { Design; "Rat- } \\
\text { packing" } \\
\text { Mitigation }\end{array}$ & $\begin{array}{c}\text { Mistake/Inadvertent } \\
\text { Action }\end{array}$ \\
\hline $\begin{array}{c}\text { Work Organization } \\
\text { Leadership }\end{array}$ & $\begin{array}{l}\text { Leadership } \\
\text { Training; } \\
\text { Consensus }\end{array}$ & $\begin{array}{l}\text { Conflicts with } \\
\text { Leadership }\end{array}$ & $\begin{array}{c}\text { Crisis } \\
\text { Resolution; } \\
\text { Chain of } \\
\text { Command } \\
\end{array}$ & Conflicting Actions \\
\hline Task Assignment & $\begin{array}{c}\text { Task Selection; } \\
\text { Task Assignment } \\
\text { Model vs. } \\
\text { Military Model; } \\
\text { Task } \\
\text { Alternatives; } \\
\text { Emergent Task } \\
\text { Performance }\end{array}$ & $\begin{array}{l}\text { Monotony; } \\
\text { Boredom }\end{array}$ & $\begin{array}{l}\text { Task Rotation; } \\
\text { Task Assignment } \\
\text { Model vs. } \\
\text { Military Model; } \\
\text { Emergent Task } \\
\text { Performance }\end{array}$ & $\begin{array}{c}\text { "Familiarity Breeds } \\
\text { Contempt"; Lack of } \\
\text { Caution }\end{array}$ \\
\hline $\begin{array}{c}\text { Physical } \\
\text { Limitations }\end{array}$ & $\begin{array}{c}\text { Crew Selection; } \\
\text { Physical } \\
\text { Endurance; } \\
\text { Ecological } \\
\text { Considerations } \\
\text { in } \\
\text { Design/Environ- } \\
\text { ment }\end{array}$ & $\begin{array}{c}\text { Strain on } \\
\text { Endurance }\end{array}$ & $\begin{array}{c}\text { Mandatory } \\
\text { Physical } \\
\text { Exercise } \\
\text { Regimen; } \\
\text { Ecological } \\
\text { Considerations } \\
\text { in } \\
\text { Design/Environ- } \\
\text { ment } \\
\end{array}$ & $\begin{array}{c}\text { "Cutting Corners"; } \\
\text { Physical Inability to } \\
\text { Perform Tasks }\end{array}$ \\
\hline $\begin{array}{l}\text { Scheduling and } \\
\text { Coordination } \\
\text { Conflicts }\end{array}$ & $\begin{array}{c}\text { Group } \\
\text { Activities and } \\
\text { Meetings; In- } \\
\text { flight Crew } \\
\text { Coordination; } \\
\text { Onboard } \\
\text { Training }\end{array}$ & $\begin{array}{l}\text { Low Morale and } \\
\text { Motivation }\end{array}$ & $\begin{array}{c}\text { Crew/Buddy } \\
\text { Checks and } \\
\text { Drills; In-flight } \\
\text { Crew } \\
\text { Coordination; } \\
\text { Onboard } \\
\text { Training }\end{array}$ & $\begin{array}{l}\text { Lack of Effective } \\
\text { Crew Interaction }\end{array}$ \\
\hline
\end{tabular}


Figure 6.e. Crew Incapacitation

\begin{tabular}{|c|c|c|c|c|}
\hline STRESSORS & $\begin{array}{c}4 \\
\text { COUNTER- } \\
\text { MEASURES } \\
\text { AGAINST } \\
\text { STRESS }\end{array}$ & $\begin{array}{c}\text { DEGRADED } \\
\text { PERFORMANCE }\end{array}$ & $\begin{array}{c} \\
\text { COUNTER- } \\
\text { MEASURES } \\
\text { AGAINST } \\
\text { ERRORS }\end{array}$ & $\begin{array}{c}\text { SAFETY } \\
\text { HAZARD }\end{array}$ \\
\hline $\begin{array}{c}\text { Space Sickness; } \\
\text { Gas Bubbles in } \\
\text { Water }\end{array}$ & $\begin{array}{c}\text { Selection; } \\
\text { Adjustment; } \\
\text { Maintain/Check } \\
\text { Water System; } \\
\text { Appropriate } \\
\text { Health Effect } \\
\text { Studies; } \\
\text { Common } \\
\text { Standards of } \\
\text { Space Industrial } \\
\text { Safety }\end{array}$ & $\begin{array}{c}\text { Poor Task } \\
\text { Performance; Gas } \\
\text { Pains }\end{array}$ & $\begin{array}{c}\text { Treatment; } \\
\text { Improve Water } \\
\text { System }\end{array}$ & $\begin{array}{c}\text { Crew Failures to } \\
\text { Respond }\end{array}$ \\
\hline Illness & $\begin{array}{c}\text { Examinations } \\
\text { and Health } \\
\text { Maintenance } \\
\text { Program; } \\
\text { Appropriate } \\
\text { Health Effect } \\
\text { Studies; } \\
\text { Common } \\
\text { Standards of } \\
\text { Space Industrial } \\
\text { Safety } \\
\end{array}$ & $\begin{array}{c}\text { Short Term } \\
\text { Incapacitation }\end{array}$ & Treatment & Contagion? \\
\hline Injury & $\begin{array}{c}\text { Space } \\
\text { Industrial } \\
\text { Safety: Common } \\
\text { Standards }\end{array}$ & $\begin{array}{c}\text { Long Term } \\
\text { Incapacitation }\end{array}$ & $\begin{array}{l}\text { Return to } \\
\text { Earth? } \\
\text { Stabilize on } \\
\text { Orbit? }\end{array}$ & $\begin{array}{l}\text { Distraction of Other } \\
\text { Crew Members; } \\
\text { Injury and Death of } \\
\text { All the Crew }\end{array}$ \\
\hline $\begin{array}{c}\text { Emotional/Mental } \\
\text { Problem }\end{array}$ & $\begin{array}{c}\text { Crew Selection } \\
\text { and Training; } \\
\text { Perform Studies; } \\
\text { Counseling }\end{array}$ & $\begin{array}{c}\text { Lack of Trust and } \\
\text { Cooperation }\end{array}$ & $\begin{array}{l}\text { Relief from } \\
\text { Duty; } \\
\text { Counseling }\end{array}$ & $\begin{array}{c}\text { Abnormal } \\
\text { Behavior; } \\
\text { Detrimental Actions }\end{array}$ \\
\hline $\begin{array}{c}\text { Failure in Life } \\
\text { Support System }\end{array}$ & $\begin{array}{c}\text { Abandon, } \\
\text { Evacuate One } \\
\text { Module; } \\
\text { Regular } \\
\text { Maintenance of } \\
\text { systems; Back- } \\
\text { up Components } \\
\end{array}$ & $\begin{array}{c}\text { Confinement, } \\
\text { Trauma }\end{array}$ & $\begin{array}{c}\text { Repairs, } \\
\text { Replacement; } \\
\text { Regular } \\
\text { Maintenance of } \\
\text { systems; Back- } \\
\text { up Components }\end{array}$ & $\begin{array}{l}\text { Loss of Access to } \\
\text { Critical Functions }\end{array}$ \\
\hline $\begin{array}{l}\text { Death of Crew, } \\
\text { Family or Friend }\end{array}$ & $\begin{array}{c}\text { Counseling; } \\
\text { Crew Training in } \\
\text { Counseling; } \\
\text { Reliable } \\
\text { Communications }\end{array}$ & $\begin{array}{l}\text { Trauma to Crew; } \\
\text { Disruption of } \\
\text { Teamwork }\end{array}$ & $\begin{array}{c}\text { Counseling; } \\
\text { Crew Training } \\
\text { in Counseling; } \\
\text { Reliable } \\
\text { Communications }\end{array}$ & $\begin{array}{l}\text { Preservation or } \\
\text { Disposal of Body; } \\
\text { Inability to Work }\end{array}$ \\
\hline
\end{tabular}


Figure 6.f. Personal Choice

\begin{tabular}{|c|c|c|c|c|}
\hline STRESSORS & $\begin{array}{c} \\
\text { COUNTER- } \\
\text { MEASURES } \\
\text { AGAINST } \\
\text { STRESS }\end{array}$ & $\begin{array}{c}\text { DEGRADED } \\
\text { PERFORMANCE }\end{array}$ & $\begin{array}{c} \\
\text { COUNTER- } \\
\text { MEASURES } \\
\text { AGAINST } \\
\text { ERRORS }\end{array}$ & $\begin{array}{c}\text { SAFETY } \\
\text { HAZARD }\end{array}$ \\
\hline $\begin{array}{c}\text { Cooking/Eating } \\
\text { Habits } \\
\text { (Restrictions) }\end{array}$ & $\begin{array}{c}\text { Shared Meals; } \\
\text { Accommodatio } \\
\text { n for } \\
\text { Individual } \\
\text { Crew } \\
\text { Preference; } \\
\text { More Food } \\
\text { Choices; } \\
\text { Adequate } \\
\text { Training in } \\
\text { Food } \\
\text { Preparation } \\
\text { Systems }\end{array}$ & $\begin{array}{l}\text { Irritation, } \\
\text { Depression }\end{array}$ & $\begin{array}{c}\text { Adequate } \\
\text { Training }\end{array}$ & $\begin{array}{c}\text { Fire, Odors, } \\
\text { Outgassing }\end{array}$ \\
\hline $\begin{array}{c}\text { Individual } \\
\text { Property } \\
\text { (Restrictions) }\end{array}$ & $\begin{array}{c}\text { Education; } \\
\text { Monitoring } \\
\text { and Control; } \\
\text { Crew Training }\end{array}$ & $\begin{array}{c}\text { Personal Autonomy } \\
\text { Diminished; Low } \\
\text { Morale }\end{array}$ & $\begin{array}{c}\text { Monitoring and } \\
\text { Control }\end{array}$ & $\begin{array}{c}\text { Outgassing, } \\
\text { Contamination, } \\
\text { Flammability; } \\
\text { Irritation; Conflict; } \\
\text { Feelings of } \\
\text { Infringement }\end{array}$ \\
\hline $\begin{array}{l}\text { Boredom, } \\
\text { Monotony }\end{array}$ & $\begin{array}{c}\text { Entertainment; } \\
\text { Crew-selected } \\
\text { Activities; } \\
\text { Architectural } \\
\text { Design }\end{array}$ & Lack of Vigilance & $\begin{array}{c}\text { Adequate Crew } \\
\text { Activities; } \\
\text { Planning and } \\
\text { Scheduling }\end{array}$ & $\begin{array}{l}\text { Practical Jokes, } \\
\text { Distraction, } \\
\text { Accidents }\end{array}$ \\
\hline Clothing & $\begin{array}{c}\text { Variety, } \\
\text { Laundry, Crew } \\
\text { Preference }\end{array}$ & $\begin{array}{c}\text { Irritation, } \\
\text { Discomfort, Less } \\
\text { Personal Freedom }\end{array}$ & Clean Filters & $\begin{array}{c}\text { Lint Problem, } \\
\text { Contamination, } \\
\text { Fire }\end{array}$ \\
\hline $\begin{array}{l}\text { Personal Habits: } \\
\text { Alcohol, Drugs; } \\
\text { Contrary Use of } \\
\text { Toilet; Irritation } \\
\text { Music }\end{array}$ & $\begin{array}{c}\text { Crew Selection, } \\
\text { Crew Training; } \\
\text { Counseling }\end{array}$ & $\begin{array}{c}\text { Effects of Overuse; } \\
\text { Withdrawal } \\
\text { Symptoms }\end{array}$ & $\begin{array}{l}\text { Counseling; } \\
\text { Evacuation } \\
\text { Counseling }\end{array}$ & $\begin{array}{c}\text { Fire; Impaired } \\
\text { Judgment; } \\
\text { Conflict; Abnormal } \\
\text { Behaviors }\end{array}$ \\
\hline
\end{tabular}

\section{Acknowledgments}

The author wishes to acknowledge Dr. Marc Cohen for his institutional memory of the Space Station Crew Safety Alternatives Study and to Mr. Thomas Gangale for his data concerning space station configurations.

This study owes many of its insights to National Science Foundation research grants SBR-9729957 and SES9944042.

\section{References}

${ }^{1}$ Peercy, R. L., Jr.; Raasch, R. F.; Rockoff, L. A., (1985, June) Space Station Crew Safety Alternatives Study-Final Report: Volume I -Final Summary Report, NASA CR 3854, Washington DC: NASA Scientific and Technical Information Branch.

${ }^{2}$ Raasch, R. F., Peercy, R. L., Jr., and Rockoff, L. A., (1985, June), Space Station Crew Safety Alternative Study - Final Report: Volume II - Threat Development, NASA CR-3855, Washington DC: NASA Scientific and Technical Information Branch. 
${ }^{3}$ Rockoff, L. A.; Raasch, R. F.; Peercy, R. L., Jr.(1985, June) Space Station Crew Safety Alternatives Study-Final Report: Volume III-Safety Impact of Human Factors, N ASA CR-3856, Rockwell International, Washington DC: NASA Scientific and Technical Information Branch.

${ }^{4}$ Peercy, R. L., Jr.; Raasch, R. F.; Rockoff, L. A., (1985, June) Space Station Crew Safety Alternatives Study-Final Report: Volume IV - Appendices, NASA CR 3857, Washington DC: NASA Scientific and Technical Information Branch.

${ }^{5}$ Mead, G. H.; Peercy, R. L., Jr.; Raasch, R. F., (1985, June) Space Station Crew Safety Alternatives Study-Final Report: Volume V - Space Station Safety Plan, NASA CR 3858, Washington DC: NASA Scientific and Technical Information Branch.

${ }^{6}$ Dudley-Rowley, M., Bishop, S., Farry, K., Gangale, T., (2000, May) “The Long-Duration Mission: Not Just Duration,” Presentation for the 13th Man in Space Symposium, International Academy of Astronautics and the Greek Aerospace Medical Association, Santorini, Greece.

${ }^{7}$ Dudley-Rowley, M., Whitney, S., Bishop, S., Caldwell, B., Nolan P.D., (2001, July) “Crew Size, Composition, and Time: Implications for Habitat and Workplace Design in Extreme Environments," Presentation for the 31st International Conference on Environmental Systems (ICES), Orlando, Florida, USA.

${ }^{8}$ Dudley-Rowley, M., Bishop, S., (2002, October)“Extended Mission Systems Integration Standards for the HumanEnvironment and Human-Human Interfaces," Presentation for the First AeroSpace Architecture Symposium, World Space Congress, October 2002, Houston, Texas, USA.

${ }^{9}$ Dudley-Rowley, M., Okushi, J., Gangale, T., Flores, P., and Diaz, E., (2003, September), "Design Implications of Latent Challenges to the Long-Duration Space Mission," Presentation for the American Institute of Aeronautics and Astronautics Space 2003 Conference in Long Beach, California, USA.

${ }^{10}$ Burrough, B., (1998) Dragonfly: NASA and the Crisis Aboard Mir, New York: HarperCollins.

${ }^{11}$ Dudley-Rowley, M., (1995, April) "Modeling Social Interaction for the Nauvik Project, a Closed Ecological Life Support System, Fairbanks, Alaska" Presentation for the Space Medicine and Life Sciences Conference, NASA, Institute of Aeronautics and Astronautics, National Institutes of Health, and the United State Air Force, Houston, Texas, USA.

\section{Secondary References}

Ball, J.R., Evans, Jr., C.H, (2001) Safe Passage: Astronaut Care for Exploration Missions, Washington, D.C.: National Academy Press.

Cohen, Marc M., (2001, July) "Space Laboratories" Presentation for the $31^{\text {st }}$ International Conference on Environmental Systems, Society of Automotive Engineers, Orlando, Florida, USA.

Foale, C., (1999) Waystation to the Stars: The Story of Mir, Michael, and Me, London: Headline Book Publishing.

Dudley-Rowley, M., (1999, May) “Team Optimization in Joint Russian and Non-Russian Extreme Environments Expeditions and Missions," Requested Presentation for the Department of Defense Human Factors Engineering Technical Advisory Group, Alexandria, Virginia, USA.

Kuznetz, L.H. (2003) "Human Life Sciences Research Aboard the International Space Station and the Space Shuttle: A White Paper," http://www.spaceref.com/news/viewsr.html?pid=10726

Linenger, J.M., (2000) Off the Planet: Surviving Five Perilous Months Aboard the Space Station Mir, New York: McGrawHill. 